\title{
Infantile Amnesia: A Critical Period of Learning to Learn and Remember
}

\author{
(1)Cristina M. Alberini and Alessio Travaglia \\ Center for Neural Science, New York University, New York, New York 10003
}

Infantile amnesia, the inability of adults to recollect early episodic memories, is associated with the rapid forgetting that occurs in childhood. It has been suggested that infantile amnesia is due to the underdevelopment of the infant brain, which would preclude memory consolidation, or to deficits in memory retrieval. Although early memories are inaccessible to adults, early-life events, such as neglect or aversive experiences, can greatly impact adult behavior and may predispose individuals to various psychopathologies. It remains unclear how a brain that rapidly forgets, or is not yet able to form long-term memories, can exert such a long-lasting and important influence. Here, with a particular focus on the hippocampal memory system, we review the literature and discuss new evidence obtained in rats that illuminates the paradox of infantile amnesia. We propose that infantile amnesia reflects a developmental critical period during which the learning system is learning how to learn and remember.

\section{The long-lasting influence of episodic infantile experiences} and the paradox of infantile amnesia

How do we develop our abilities to learn and remember facts, people, things, relationships, and places? These memories define our identities; they store autobiographical episodes that can be consciously declared, and are therefore termed declarative memories. Declarative memories include both the experience of specific things, people, and events of a given time and place (episodic memories), and general knowledge about the world (semantic memories). They are also known as explicit memories because they require conscious recollection (Graf and Schacter, 1985). These are the memories that are lost in Alzheimer's disease or aging-related memory impairment. Parallels of these memories exist in nonhuman animals and include contextual, spatial, and episodic memories (Ergorul and Eichenbaum, 2004). Collectively, such memories store information about "who, what, when and where," and are therefore termed "wwww" memories. In both humans and nonhuman mammals, wwww memories are processed by the hippocampus-dependent (or medial temporal lobe-dependent) learning and memory system (Eichenbaum, 2006; Squire and Wixted, 2011; Lavenex and Banta Lavenex, 2013; Albani et al., 2014).

A large body of clinical and behavioral evidence has demonstrated the critical importance of infantile episodic experiences for brain function throughout life. However, little is known about the biological mechanisms underlying the development of the hippocampus-dependent learning and memory system. Many studies have shown that hippocampus-dependent memo-

\footnotetext{
Received Feb. 6, 2017; revised May 4, 2017; accepted May 15, 2017.

This work from was supported by National Institute of Mental Health Grants MH074736, MH065635, and Agalma Foundation. We thank Dr. Regina Sullivan for comments on the manuscript.

The authors declare no competing financial interests.

Correspondence should be addressed to Dr. Cristina M. Alberini, Center for Neural Science, New York University, 4 Washington Place, Room 809, New York, NY 10003. E-mail: ca60@nyu.edu.

DOI:10.1523/JNEUROSCI.0324-17.2017

Copyright $\odot 2017$ the authors $\quad 0270-6474 / 17 / 375783-13 \$ 15.00 / 0$
}

ries (also referred to as hippocampal memories) are severely compromised by challenges occurring early in life. These challenges may be either psychological (e.g., trauma, neglect, or deprivation of social experience) or biological (e.g., the impact of genetic mutations on development). All of these events can predispose individuals to psychopathologies, such as post-traumatic stress disorder, borderline personality disorder, or autism (Heim and Nemeroff, 2001; Pryce et al., 2005; Zeanah et al., 2009; Bale et al., 2010; Perry and Sullivan, 2014).

Neglect during early development can produce severe psychopathologies, such as depression and anxiety, as well as learning and cognitive disabilities (Rutter, 1998; Lyons-Ruth et al., 2006; Nelson et al., 2007; Bos et al., 2010; Pollak, 2015; Fisher, 2016; Teicher and Samson, 2016). One well-studied example of severely impoverished experience during early development involves a group of children in Bucharest who were abandoned and institutionalized around the time of birth. According to the $\mathrm{Bu}$ charest Early Intervention Project, which has followed these cases for up to 20 years, the children experienced very little interaction, support, or care from the very early years of life. This deprivation resulted in high rates of mortality and developmental disabilities. Institutionalization during the first 4-5 years of life caused deficits and delays in cognitive (i.e., intelligence quotient [IQ]) and socio-emotional behaviors (i.e., attachment), and greatly increased the incidence of psychiatric disorders. These children also exhibited significant differences in brain electrical activity. For the children who were transferred to foster care, general development improved; however, improvements in brain activity (EEG), language, cognition, and social-emotional functioning were limited to very early-life sensitive periods: the earlier the children were transferred to foster care, the better was the recovery. Moreover, the sensitive period for recovery varied by functional domain; and if foster care did not start by the age of 2 years, most functions remained permanently compromised: only a few functions recovered fully, whereas others, such as attachment, emotional responsiveness, and IQ, continued to be impaired 
(Bos et al., 2010). These data suggest that several learning and cognitive functions, most of which are processed by the medial temporal lobe, are extremely sensitive to the types of experiences encountered during the early developmental period.

Developmental cognitive impairments throughout the lifetime are not limited to extreme cases, such as institutionalized children with poor resources. Poverty, a much more widespread condition, has been extensively documented to lead to severe and permanent learning deficits (Bos et al., 2010). Consequently, addressing poverty may resolve many health and economic challenges and would greatly improve life skills, psychosocial conditions, and productivity, and hence the standard of living, in all societies.

Although these clinical and psychological data highlight the importance of a critical temporal window in which early intervention can repair the effects of childhood adversity, the underlying mechanisms remain poorly understood. Recent studies suggested that poor cognitive and academic performance among children living in poverty is, at least in part, due to reduction in the size of the hippocampus and frontal and temporal lobes (Hair et al., 2015). Similarly, reduced volume of the hippocampal subregions CA3 or dentate gyrus correlates with childhood maltreatment and abuse (Teicher and Samson, 2016). It has been proposed that most of these deficits are the result of the effects of stress (Bale et al., 2010) because many studies have focused their attention on determining the effects of severe or chronic stress on development (Meaney and Szyf, 2005; Blair and Raver, 2016).

Experiments in animal models led to similar conclusions (i.e., stressful early-life experiences predispose to cognitive dysfunctions) (Meaney et al., 1988; Brunson et al., 2005; Poulos et al., 2014), and are accompanied by precocious maturation of the hippocampus, as revealed by accelerated development of inhibitory circuitry, switching of NMDAR subunit expression, and myelin maturation (Bath et al., 2016). Early-life stress also decreases adult performance in inhibitory, spatial, and recognition learning and memory (Lehmann and Feldon, 2000; Chocyk et al., 2013; Reincke and Hanganu-Opatz, 2017).

However, as discussed below, we believe that severe stress and trauma may not be the only explanation for such defects. We propose that lack of sufficient or balanced enrichment in episodic/ declarative experiences during the early phase of development may also cause learning and cognitive disabilities with severe lifelong repercussions, such as depression, addiction, and obsessivecompulsive disorder. This hypothesis is in agreement with the outcomes of several clinical studies (Heim and Nemeroff, 2001; Pryce et al., 2005; Spratt et al., 2012).

The long-term effects of early-life experiences present a paradox: hippocampal-dependent learning seems to develop relatively late in childhood; and in both humans and other animals, early episodic/declarative memories are rapidly forgotten. This memory loss is thought to be associated with infantile or childhood amnesia, the inability of adults to recall early-life events (Campbell and Spear, 1972; Hayne, 2004; Rovee-Collier and Cuevas, 2009). How, then, can memories that are rapidly forgotten, and of which there is virtually no recollection in adulthood, exert a lifelong effect on the brain and cognitive function? To date, the hypotheses proposed to explain this paradox have not been fully satisfactory.

Recent studies from our laboratory suggest a novel explanation for why experience deprivation or significant alteration of hippocampal learning in early developmental phases, when the hippocampal memory system is not yet functionally competent, leads to profound and lasting deficits in cognitive functions, in- cluding learning. Data that we obtained in rats indicate that the hippocampal memory system, like sensory functions and language, matures through experience and undergoes a developmental critical period (Travaglia et al., 2016a). Our results imply that optimal exposure to hippocampal learning during early life is key to development of an efficient, well-organized hippocampal learning system. On the other hand, deficient or deleterious experience during this critical period can predispose the individual to lifelong dysfunctions.

In this Viewpoints article, we review the current knowledge on the role of the hippocampal memory system during early development, as well as the literature on infantile amnesia, in both animal models and humans. In this context, we discuss our recent findings and propose that critical-period mechanisms in the hippocampus play fundamental roles in learning how to learn and remember. We conclude by discussing the implications of this novel model of early learning for the etiology of learning disabilities and developmental psychopathology.

\section{Hippocampus-dependent learning and its ontogeny}

In both humans and nonhuman mammals (e.g., rodents), the memories that store information about who, what, when, and where (wwww memories) are processed by the hippocampus and related structures of the medial temporal lobe (Eichenbaum, 2006; Squire and Wixted, 2011). For simplicity, we will refer to these memories as hippocampus-dependent memories or hippocampal memories.

The hippocampus does not process and store memories in isolation, but instead cooperates with other medial temporal lobe and cortical regions, which, as network ensembles, execute the processes of encoding, stabilization (consolidation), maintenance (storage), and retrieval of memories. Together, these structures comprise the hippocampus-dependent memory system (Preston and Eichenbaum, 2013; Squire et al., 2015). Upon learning, these network ensembles undergo long-lasting physical changes, which are referred to as memory traces or engrams. These changes, which are necessary for memory consolidation and storage, evolve over time. First, the hippocampus, along with the primary, secondary, and association cortices, initiates memory consolidation, the process that stabilizes the new, fragile memory trace. This initial phase of consolidation, known as cellular/molecular consolidation, requires de novo gene expression (Dudai, 2012). With time, the engram shifts from hippocampalcortical to primarily cortical areas, thus becoming hippocampusindependent, a process known as system consolidation (Dudai, 2012). Notably, when memories maintain autobiographical details, they may remain dependent on the hippocampus for their recall (Moscovitch et al., 2016).

The identification and characterization of the hippocampusdependent memory system and its functions emerged from analyses of clinical cases in which the hippocampi and/or related structures had been damaged or lost. One well-studied example is the patient H.M., who underwent bilateral resection of the medial temporal lobe for intractable epilepsy (Scoville and Milner, 1957). After surgery, the patient experienced a dramatic improvement in epileptic symptoms but developed severe anterograde and temporally graded retrograde amnesia selective for autobiographical/ episodic and declarative memories. By contrast, his working memory was intact, as were his intellectual abilities and motor learning. Similar results have been obtained with hippocampal lesions or inactivation in animal models (Kim and Fanselow, 1992; Bambah-Mukku et al., 2014). Hence, both human and animal model studies have identified the hippocampus as a key 
player in the formation of long-term memories related to events and their temporal and spatial bindings. These studies also distinguished the wwww memories from other types of memories, which were spared in amnesic patients and animal models with hippocampal lesions. The spared memories were classified as nondeclarative or implicit, which, in contrast to declarative memories, can be recalled automatically without conscious effort (Tulving, 2005; Squire and Wixted, 2011).

If distinct memory systems (i.e., explicit and implicit) exist in adult brains, how do they actually develop? More specifically, how does the hippocampus-dependent memory system mature?

Memory system ontogeny has been extensively studied in human and animal models at the psychological and behavioral levels. The results of these studies were initially controversial: researchers disagreed about the criteria for classification of implicit versus explicit learning and memory in early development, as well as whether and when hippocampus-dependent memories are formed in early life. Some authors argued that infants lack the capacity for explicit/declarative long-term memory, and pointed out that, because infants lack language ability, it is difficult to establish whether they can experience conscious recollection of tasks (Schacter and Moscovitch, 1984; Tulving, 2005). On the other hand, other authors proposed that infants are perfectly capable of expressing explicit memories under behavioral paradigms appropriate to their developmental stage (Hayne, 2004; Rovee-Collier and Cuevas, 2009).

Although this controversy remains only partially resolved, most investigators involved in both human and animal studies agree that infants can form long-lasting memories, but exhibit faster rates of forgetting, and that the expression of different types of memories in early development differs greatly from that in adults. It is also well established that the implicit memory system is functional starting from birth, whereas the explicit memory system reaches functional maturity much later (Rovee-Collier and Cuevas, 2009).

A consensus has also been reached that the maturation of implicit and explicit memory systems progresses in phases that are adapted to the available capacity. For example, for nipple location and nursing, starting immediately after birth, rat pups engage in somatosensory learning associated with the whisker system (Landers and Sullivan, 1999). This learning likely involves the sense of smell, which is functional in newborn rats (Alberts, 1984), whereas hearing and vision arise later, around postnatal day (PN) 13-14 (Freeman et al., 1999; de Villers-Sidani et al., 2007). As the complexity of somatosensory information processing develops, different and more complex behavioral responses emerge. Likewise, threatening experiences that occur very early in life are processed very differently than in later developmental phases and adulthood. If pups at PN10 or younger are presented with aversive stimuli paired with a novel odor, they show a preference rather than aversion for the odor (Sullivan et al., 1986). This approach response, which is not due to deficits in pain processing, seems to be linked to immaturity of the threat learning system. Indeed, the infantile experience appears to activate a very different neural circuit in pups than in adults (Shionoya et al., 2006). The adult-like fear response emerges at $\sim$ PN12-PN15, with the maturation of the amygdala, a region critical for threat response processing (Bouwmeester et al., 2002; Moriceau and Sullivan, 2006; Moriceau et al., 2006; Chareyron et al., 2012).

At a similar age (PN10-P12), however, the rat hippocampus remains very immature, with consistent performance in spatial and contextual learning only emerging much later. The ability to perform most hippocampal-dependent tasks, including sponta- neous alternation, spatial navigation, and contextual fear conditioning, develops no earlier than PN17 (Campbell and Spear, 1972). Moreover, at this stage (PN17), spatial, contextual, and episodic information can be learned and retained, but only for a short period of time. These memories do not persist and are apparently rapidly forgotten, a phenomenon that, as mentioned above, parallels infantile amnesia (Campbell and Spear, 1972). Hippocampal-type memories are observed more consistently starting at $\sim$ PN21 (Rudy et al., 1987; Kraemer and Randall, 1995; Stanton, 2000; Blair et al., 2013), with adult-like performance arising only after adolescence. For example, spatial learning and memory, as investigated using the water maze task, is observed at PN20-P21 (Stanton, 2000; Akers and Hamilton, 2007), initially appearing as directional learning and later as spatial learning at $\sim$ PN26-PN27 (Akers et al., 2009; Ainge and Langston, 2012). Similarly, contextual memories, studied using contextual fear conditioning, are observed at PN18 but rapidly decay, and their retention comes to resemble that in adult rats starting at PN23 (Pugh and Rudy, 1996). Other hippocampal-type learning, such as context pre-exposure facilitation, emerges at PN23-PN24 (Jablonski et al., 2012). Similar patterns are observed in the ontogeny of trace fear conditioning, a type of associative learning in which the animal learns to temporally separate the conditioned stimulus (CS) from the unconditioned stimulus (US) by an extended interstimulus interval. Trace fear-conditioning manifests according to the modal properties of the CS: it is detected at PN21 with an auditory CS, and at PN30 with a visual CS (Moye and Rudy, 1987). PN30 rats are also proficient in trace eyeblink conditioning (another behavior that is hippocampus-dependent in adult animals), whereas PN19 rats have deficits in retaining such memories (Ivkovich et al., 2000). Finally, PN24 rats can learn to recognize novel objects but cannot yet express object location learning, whereas PN30 rats successfully express both behaviors (Ainge and Langston, 2012).

Together, these studies revealed that simple forms of hippocampal contextual, object, and spatial memory are encoded by rats starting at PN17; however, these memories are not expressed over the long term. Only when memories are encoded starting at PN23-P24 do the juveniles exhibit retention similar to that of adult rats. Furthermore, more complex experiences, such as spatial recognition, which are hippocampus-dependent in adult animals, can only be expressed over the long term by more mature animals. Hence temporal and complexity gradients accompany the ontogeny of hippocampal learning and memory.

Based on the age of emergence of learning and cognitive functions, Madsen and Kim (2016) proposed that rats at PN10-PN12 are approaching the end of infancy (equivalent to 12 months in humans), and at PN12-PN21 are in the juvenile period (1-7 years in humans). Consistent with this ordering, similar behavioral temporal outcomes have been observed in human studies (e.g., memory retention becomes more persistent in older infants). For example, at 6 months, infants recollect imitated actions for $24 \mathrm{~h}$ (Meltzoff, 1988), at 9 months for up to 5 weeks, and at 10 months for up to 3 months (Carver and Bauer, 2001; Mullally and Maguire, 2014). Studies that investigated wwww memories in children, such as the hide-and-seek paradigm (Hayne and Imuta, 2011) or the identification of details related to where an event occurred (Bauer et al., 2012), suggested that episodic memory skills appear by the age of 3 years. The studies also revealed that it is the ability to retain (as opposed to form) episodic memories that increases with age: 3-year-old children have good short-term recollection but do not maintain the memories for long periods of time (Scarf et al., 2013). 
In summary, it has been widely documented in both humans and rodents that hippocampal-type learning takes longer to develop (up to $21 \mathrm{~d}$ in rats and $\sim 3$ years in humans) than learning processed by implicit memory systems. Importantly, during their initial phase of development, explicit memories can be acquired and expressed over the short term, but their retention decays quite rapidly, a forgetting that is proposed to be associated to infantile amnesia (Meltzoff, 1988; Carver and Bauer, 2001; Hayne and Imuta, 2011; Bauer et al., 2012; Scarf et al., 2013; Callaghan et al., 2014; Mullally and Maguire, 2014; Madsen and Kim, 2016).

\section{Infantile amnesia and explanatory hypotheses proposed to date}

As mentioned before, infantile or childhood amnesia is the inability of human adults to remember episodic experiences that occurred during the first few years of life (generally $0-3$ years) and the tendency to have sparse recollection of episodic experiences that occurred before age 10 (Kihlstrom and Harackiewicz, 1982; Rubin, 2000; Newcombe et al., 2007). This phenomenon occurs in the vast majority of cases. Very rare exceptions have been reported, such as the case of Shereshevsky (or "S"), the mnemonist studied by Alexander Luria (1968); however, S processed memories in a very peculiar manner. Infantile amnesia was first described by Caroline Miles in 1893 and Henri and Henri, (1895). Sigmund Freud (1953) offered the first explanation of this phenomenon: based on his psychoanalytic theory, he postulated that early life events are repressed due to their inappropriately sexual nature. Although this hypothesis of repression is highly debated, the observation that early memories are "forgotten," or unable to be explicitly expressed, is supported by many studies in humans (Davis and Rovee-Collier, 1983; Hayne, 2004; Rovee-Collier and Cuevas, 2009). The lack of recollection of infantile experiences by adults cannot be explained simply by the passage of time or difference in encoding ability, suggesting that processing and retention of hippocampus-dependent memories differ over the course of development.

A phenomenon similar to human infantile amnesia has been reported in animals, not only for hippocampus-dependent memories such as contextual and spatial memories, but also for hippocampus-independent memories such as cued conditioning and conditioned taste aversion (Schweitzer and Green, 1982). Here, we will limit our discussion to hippocampus-dependent memories. Early studies of rat pups conditioned to avoid a shockpaired compartment showed that young animals forget much faster than older ones (Campbell and Campbell, 1962). These findings were subsequently replicated, using a range of learning paradigms, in multiple species that undergo extensive postgestational development, suggesting that rapid forgetting that parallels infantile amnesia is an evolutionarily conserved phenomenon (Campbell and Jaynes, 1966; Feigley and Spear, 1970; Schulenburg et al., 1971; Steinert et al., 1980; Greco et al., 1986; Anderson et al., 2004).

Why are early memories rapidly forgotten? Several hypotheses have been proposed to address this question. Human and cognitive psychologists have suggested that autobiographical memories fade rapidly because young children have not yet acquired language abilities, and consequently lack the ability to encode and express autobiographical events (Harley and Reese, 1999). Proponents of this hypothesis have also suggested that young children have not yet developed a sense of "self" or a "theory of mind," and therefore cannot organize and store memories as autobiographical experiences (Perner and Ruffman, 1995). However, these explanations cannot account for the rapid forgetting observed in animals. Thus, although development and cognition differ between animals and humans, the striking similarities in rapid infantile forgetting between humans and other animals demand neurobiological explanations.

Experimental evidence has shown that rapid infantile forgetting cannot be explained by insufficient learning: infant and young animals learn similarly to, and in specific tasks even better than, adult animals, but forget significantly more rapidly (Kirby, 1963; Feigley and Spear, 1970; Campbell and Spear, 1972; Greco et al., 1986). What causes this rapid forgetting? Is it lack of memory consolidation, defective memory storage, or impaired memory retrieval?

One widely supported hypothesis, often referred to as the "developmental hypothesis," posits that early wwww memories are not stored over the long term because the hippocampus is immature and therefore unable to process, consolidate, and store contextual and episodic representations (Bauer, 2006; Newcombe et al., 2007). In support of this hypothesis, excitatory synaptic transmission in the rat hippocampus, which is necessary for adult-like synaptic plasticity and memory, only begins to mature around the third postnatal week (Albani et al., 2014). Moreover, at this stage, the cortical regions involved in system consolidation remain immature. One of these regions is the mPFC, which comprises the prelimbic and infralimbic cortices. In both humans and rodents, the mPFC develops slowly over an extended period and continues to increase in synapse density and maturity until $\sim$ PN24 (Huttenlocher, 1979; Van Eden and Uylings, 1985; Zhang, 2004). Juvenile rats do not recruit the prelimbic cortex in fear memory expression, whereas this region is absolutely critical in later stages, from preadolescence onward (Kim et al., 2012). The results of morphological studies of human brains are consistent with data obtained in rodents: in both species, the prefrontal cortex and the dentate gyrus of the hippocampus undergo extended postnatal maturation. The human hippocampus reaches some degree of functional maturity no earlier than 20-24 months (Huttenlocher and Dabholkar, 1997), and possibly later in some subcircuits, as suggested by studies in monkeys (Lavenex and Banta Lavenex, 2013). The human hippocampus reaches full maturity around the end of preschool (i.e., 3-5 years), an age that corresponds with the offset of infantile amnesia, whereas the prefrontal cortex does not reach full maturity until early adulthood (GoldmanRakic, 1987).

Also supporting the developmental hypothesis, recent studies reported that neurogenesis of the subgranular zone of the dentate gyrus, which occurs at a much higher rate early in development to integrate neurons into the hippocampal circuit, may destabilize memory representation, thereby contributing to the rapid forgetting of infantile memories (Akers et al., 2014).

In contrast to the developmental hypothesis, which argues that memories are lost, an alternative hypothesis posits that infantile memories are not gone, but are instead stored in some form that cannot be expressed due to retrieval failure (Li et al., 2014). This hypothesis, referred to as the retrieval hypothesis, is motivated by observations in humans and animal models that "reminders" (e.g., reencounters with parts of the original experience associated with the memory) can prevent rapid forgetting, as demonstrated by expression of the memory for longer periods of time. For example, in conditioned shock-avoidance, the presentation of a shock (the US) at weekly intervals maintains or "reinstates" a strong memory for several weeks (Campbell and Jaynes, 1966). The US reinstates the memory immediately after its presentation, suggesting that the amnesia is due to retrieval failure (Spear and Parsons, 1976). Similar outcomes have been observed 


\section{Inhibitory Avoidance (IA)}
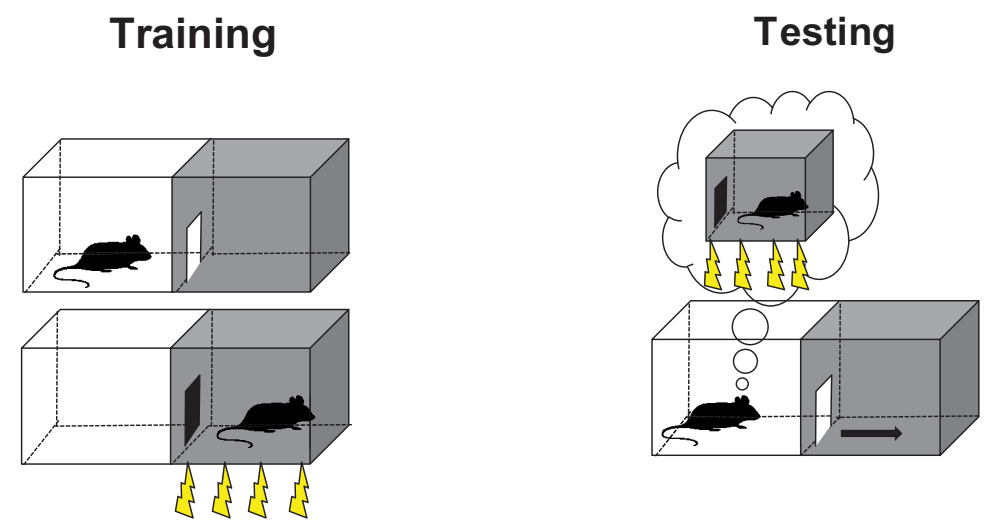

Figure 1. Schematic representation of the IA task used in our studies. During the training session, the rat is placed in the lit (safe) compartment of a two-chamber apparatus. After $10 \mathrm{~s}$, the door separating the compartments is automatically opened, allowing the rat access to the dark (shock) compartment. Because of their exploratory drive and nocturnal nature, the rats quickly enter the dark compartment. The time the rat takes to enter the dark compartment is taken as acquisition latency. Upon entering, the door is closed, and a mild electric footshock is delivered from the grid floor. A few seconds later, the rat is returned to the home cage. During testing, the rat is placed back into the lit compartment, and the time the animal takes (latency) to enter the dark compartment is measured (test). Under normal conditions, the animals develop a significant avoidance of the compartment that was previously associated with the footshock. The latency score is used as a behavioral readout of the memory of the context that was previously associated with experiencing a footshock.

in Pavlovian fear conditioning in rats (Kim and Richardson, 2007) and 8-week-old babies (Rovee-Collier et al., 1980; Davis and Rovee-Collier, 1983). Moreover, in both animal models and humans, forgetting is alleviated if, during memory testing, the subject re-experiences internal or external contextual cues similar to those presented at training (Rovee-Collier et al., 1980; Davis and Rovee-Collier, 1983; Spear, 1984; Richardson et al., 1986). In sum, numerous studies across species have supported the conclusion that early developmental memories are not lost, but instead suffer from retrieval impairments.

In support of the idea that infantile experiences are stored over the long term, persistent relevant biological changes have been detected in rat models. For example, one study examined NMDAR dependence, a signature of new memory acquisition and absent in relearning, in infant rats (Li and Richardson, 2013). Although infantile memories were forgotten, the rats exhibited NMDARindependent relearning, suggesting that infantile learning produces long-lasting biological changes, even though the associated memories are unavailable for expression (Chan et al., 2015).

If memories from early life are stored over the long term, what mechanisms are involved in rescuing or promoting their retrieval or expression? One explanation, proposed by Li et al. (2014), involves modulation. Episodic memories are consolidated and stored over the long term if the experience is salient; thus, an internal state of arousal may be required for recall of an inaccessible memory. In other words, according to this view, expression of the infantile experience is state-dependent. Consistent with this idea, adrenaline or noradrenaline injected days after training rescues memory loss in juvenile rats trained in passive avoidance (Haroutunian and Riccio, 1977; Gold et al., 1982). The inhibitory neurotransmitter GABA was also reported to modulate infantile forgetting: specifically, GABA inverse agonists alleviate infantile forgetting when administered early in development but have no effect if given in adulthood, supporting the interpretation that high GABA inhibition contributes to infantile amnesia (Kim et al., 2006). Furthermore, stress hormone-mediated modulation has been studied extensively because early stressful experiences, such as maternal separation, lead to the formation of more persistent memories during infancy (Callaghan and Richardson, 2012). This faster maturation may be the result of more rapid development of amygdala-mPFC connectivity, which is mediated by cortisol, as demonstrated by recent studies in humans (Gee et al., 2013); it may also be due to more rapid maturation of the neuroendocrine response to fear (Ganella et al., 2015).

The developmental and retrieval hypotheses disagree on the primary explanation for infantile amnesia, and both models leave several questions unanswered: how does an immature hippocampal memory system store memories that, although not expressed, can still influence behavior in adulthood? Moreover, is the hippocampus, although immature, critically involved in the encoding and consolidation of these nonexpressed memories, or are these memories in the immature brain processed by a different system, without the involvement of the hippocampus? Our recent findings regarding the mechanisms underlying infantile hippocampal learning provide new, plausible answers to these questions.

\section{Mechanisms of infantile hippocampal learning}

We recently investigated infantile amnesia in rats using a single aversive event, a contextual experience associated with a footshock. In this task, known as inhibitory avoidance (IA) or passive avoidance, the animal learns to avoid a context in which a footshock was previously experienced (Fig. 1). In adult animals, IA training produces hippocampus-dependent long-term memory; indeed, IA memory is disrupted by pharmacological or molecular interference applied to the dorsal hippocampus within the first day after training (Bambah-Mukku et al., 2014). IA and similar learning tasks have been used extensively in rodents to study infantile amnesia related to hippocampal memories (Campbell and Campbell, 1962; Kirby, 1963; Klein and Spear, 1969; Feigley and Spear, 1970; Schulenburg et al., 1971).

In agreement with the literature, we found that rats trained in IA at PN17 acquired the task, as demonstrated by the fact that they expressed a strong avoidance memory immediately after training, but they forgot very rapidly: the IA memory was significantly reduced $30 \mathrm{~min}$ after training and completely gone after a day (Travaglia et al., 2016a). On the other hand, rats trained at PN24 were able to form a very robust and long-lasting IA memory. Although close in developmental age to PN17 rats, PN24 rats are already competent to form and express long-term IA memories; accordingly, we used animals of this age as the reference control group.

First, we asked whether the PN17 rat memory vanished or was instead prevented from expression by some retrieval impairment. Rats trained at PN17 never remembered IA when tested, even repeatedly, days or weeks after the initial training (Fig. 2), indicating that the re-exposures to the context in which the original experience took place did not rescue the amnesia, even if they were repeated several times. Similarly, the experience of the footshock alone delivered in a distinct context (reminder shock) did 
not reverse the amnesia, again, even if repeated several times. However, if a reminder shock was delivered days after a context exposure, the rats were no longer amnesic, but instead expressed a robust and long-lasting IA memory (Fig. 2). This memory reinstatement suggests that information about the original experience encountered during the period of infantile amnesia was indeed stored and that later reminders of that experience could bring back the memory. Moreover, the expression of the memory after the context + reminder shock is very likely the result of reactivation of the original infantile memory trace, and not of new learning; no memory was expressed in rats that were exposed to the reminders but had not undergone IA training at PN17, or in rats that received a footshock not paired with the IA context at PN17 (Fig. 2). Finally, the reinstated memory was specific for the training context: if the rats were tested in distinct contexts (Context B), they showed no avoidance, indicating that the reinstated avoidance was not due to context generalization or trauma generalization (Fig. 2). These results are more consistent with the retrieval hypothesis than the developmental hypothesis. However, as our subsequent mechanistic investigations revealed, this explanation of impaired memory retrieval or expression was not fully satisfactory.

We next asked whether the hippocampus is involved in forming the memory, which can then be reinstated by the reminders. We found that blocking either the activity of the dorsal hippocampus with muscimol, or its plasticity with antibodies that block the function of the neurotrophin BDNF, at the time of training impeded memory reinstatement, indicating that the hippocampus is indeed necessary to form and store the latent memory trace. These finding were in disagreement with the developmental hypothesis, and also inconsistent with the idea that hippocampusdependent memories are lost in infancy because the hippocampus is not yet "online," and is therefore unable to process the memory. On the contrary, these data showed that the hippocampus is critical for encoding a memory that is stored over the long term, although not expressed. Because this memory lies dormant until circumstances are suitable for its manifestation, we refer to it as latent memory.

We then sought to identify the molecular mechanisms in the dorsal hippocampus that are critical for formation and storage of the latent memory trace. To this end, we performed biochemical analyses to survey possible changes in long-term plasticity mechanisms, including proteins encoded by immediate-early genes, neurotransmitter receptors, plasticity transcription factors, and growth factors. In particular, we compared the levels of these proteins in the dorsal hippocampi of rats that underwent learning

PN17
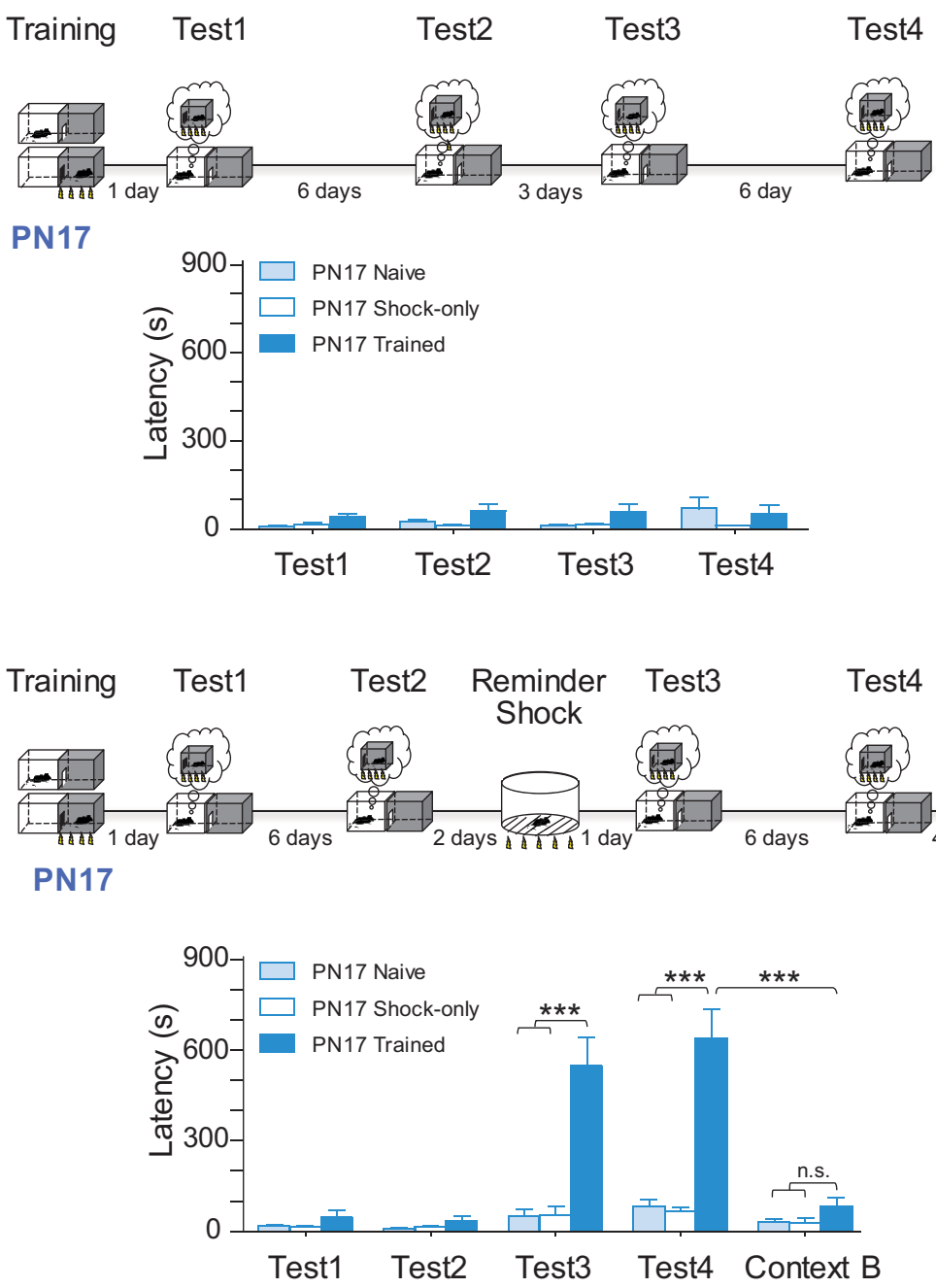

Figure 2. Latent infantile memories can be reinstated later in life following reminders. Experimental schedule is shown above each panel. Memory retention is expressed as mean latency \pm SEM. Top, Rats trained at PN17 were given contextual reminders est) repeatedly; in other words, the rats were re-exposed to the context in which the original experience took place. This protocol 2). This protocol reinstated a robust and long-lasting IA memory. When rats were tested in a different contex ), hey showed no avoidance, indicating that the reinstated memory was specific for the training context, rather than the (t) the initial acquisition, excluding the possibility that the reinstatement following the reminder shock was the result of nonspecific responses. Two-way ANOVA followed by Bonferroni post hoc test; ${ }^{* * *} p<0.001$.

at PN17 or PN24 with those of littermate rats that did not undergo learning or only received an unpaired footshock.

The results revealed an important molecular signature: associative learning at PN17, but not at PN24, significantly changed the expression of the NMDAR subunits GluN2B and GluN2A. Specifically, training at PN17 led to a significant increase in the GluN2A/2B ratio because the level of GluN2A increased more than that of GluN2B in response to learning. This finding was intriguing because similar switches had been previously identified during the developmental critical period of the visual system in response to visual stimuli (Carmignoto and Vicini, 1992; Quinlan et al., 1999) and in neonatal hippocampal slices following LTP (Bellone and Nicoll, 2007). Furthermore, it is well established that, during early development, GluN2B is the most highly expressed of the GluN2 subunits. GluN2A expression increases throughout the brain during the second postnatal week, during 
which it is dramatically upregulated. Thus, the ratio of the levels of the two NMDAR subunits changes over the course of development: GluN2B is predominant earlier, but subsequently the brain is significantly more enriched in GluN2A (Ewald and Cline, 2009).

Critical periods are temporal windows of development during which the brain is particularly sensitive and responsive to experience. It is precisely through the developmental experiences occurring during this period that the systems mature and become functionally competent. Indeed, if the relevant stimuli are not present during the critical period, functional competence is dramatically and persistently impaired. After the critical period ends, the stimuli or lack of thereof have less influence.

The biological mechanisms of critical periods have been most extensively studied in the visual system. Guided by this knowledge, we explored the roles of some of these mechanisms, specifically the function of BDNF and metabotropic glutamate receptor 5 (mGluR5), which had been reported to affect the GluN2B-to-2A switch in critical-period model systems and accelerate the closure of critical periods (Huang et al., 1999; Matta et al., 2011). We found that blocking the function of either BDNF or mGluR5 before training at PN17 impeded memory reinstatement at later times and blocked the learning-induced switch of GluN2B to 2A. Conversely, activation of mGluR5 with an agonist or administration of BDNF at training induced the switch and promoted long-term memory formation, accelerating the closure of the critical period (Travaglia et al., 2016a).

The similarities between our findings regarding mechanisms of hippocampal infantile learning and the mechanisms underlying the visual system critical period led us to propose that the hippocampal-dependent memory system undergoes a developmental critical period, similar to those of sensory systems. Consequently, during this period, the immature hippocampus must be highly responsive to learning. Indeed, we observed that the levels of activation and plasticity markers, such as c-Fos, Zif268, activity-regulated cytoskeleton-associated protein (Arc), and phosphorylated cAMP response element binding protein (phosphoCREB), are higher in PN17 than in PN24 or adult hippocampus (Travaglia et al., 2016b).

On the basis of these data, we offer a new working model to explain the ontogeny of hippocampus-dependent learning and memory. The hippocampal system in its infantile, immature state is highly responsive to stimuli and experience occurring during a critical period, and it is through these early developmental responses that it matures, becoming functionally competent and capable of storing information over the long-term in an expressible/ accessible fashion. In other words, we suggest that the exposure of the immature hippocampal system during its developmental critical period to a great deal of new learning, such as new episodes and contextual, spatial, and social events, results in storage of this information in an immature (and hence latent) form. This processing promotes maturation of the system to functional competence. We believe that the IA experiments, by adding a new salient experience during the critical period, allowed us to experimentally capture the mechanisms underlying hippocampal maturation. We also suggest that what is currently viewed as a developmental switch of the NMDAR from predominantly $2 \mathrm{~B}$ to predominantly $2 \mathrm{~A}$ does not occur by default but is actually an experience-driven switch that occurs during critical periods. Therefore, we believe that, during its critical period, the hippocampus does not yet perform like the adult system because it is in the process of learning how to learn and remember.
We also propose that retrievals and reminders contribute to the activation and maturation of the hippocampal memory system. As mentioned above, the hippocampus does not work in isolation; hence, we believe that the entire hippocampusdependent memory system, as well as the functional cross talk among the hippocampus, cortical regions, and amygdala, matures during the infantile critical period in response to experience. This intriguing model needs to be further interrogated at the mechanistic level. Moreover, additional hypotheses may be suggested by investigations of other critical period mechanisms, most of which have thus far been identified and studied in sensory systems.

\section{Critical periods and their mechanisms}

Critical periods have been identified in several types of learning across species. For example, greylag goose chicks imprint on moving visual objects only during a short, well-defined period that peaks between 13 and $16 \mathrm{~h}$ after hatching (Lorenz, 1935). In many bird species, hearing another bird can influence the individual's own vocal behavior only during a narrow time window in juvenile development (Immelmann, 1969; Eales, 1985). In humans, language acquisition undergoes critical-period regulation: infants and young children are better language learners compared with adults, despite adults' superior cognitive abilities (Newport et al., 2001; Knudsen, 2004; Kuhl, 2004; Bruer, 2008). Thus, several types of learning seem to undergo critical periods. Hence, in light of our data, we propose that such a process also exists for hippocampal learning. Although we have shown that some mechanisms typical of critical period previously identified in sensory systems are common to hippocampal learning during development, several questions persist regarding the mechanisms involved in hippocampal and other functional critical periods: What is the nature of all biological mechanisms underlying critical periods? Are there common or specific mechanisms of critical periods in different brain regions, and for the maturation of different functions? And finally, what are the mechanisms that frame the temporal windows of critical periods?

Wiesel and Hubel (1963) discovered that, in cats, temporary visual deprivation of one eye during early development, but not in adulthood, impacts the ocular dominance of the visual cortex and visual function. These findings paved the way to the neurobiological investigation of critical periods. Several studies sought to identify the cellular and molecular mechanisms of critical periods. One of these mechanisms was revealed to be synaptic strengthening and weakening via NMDA receptors and regulation of LTD versus LTP cell excitability and structural modifications. These changes have been observed not only in the visual cortex, but also in song learning in birds (Aamodt et al., 1996; Roberts et al., 2010) and in the barn owl's auditory localization system (Feldman and Knudsen, 1997; Takesian and Hensch, 2013). More specifically, a key mechanism associated with visual impairment caused by monocular deprivation was shown to be depression of excitatory thalamocortical synaptic transmission in layer 4 of the visual cortex (Khibnik et al., 2010; Medini, 2011; Cooke and Bear, 2014). In addition, the change in GluN2A/2B ratio was identified as a critical signature for the induction of NMDAR-dependent plasticity in the visual cortex, and mGluR5 is involved in upstream control of this plasticity (Sidorov et al., 2015). Similar mechanisms were observed in hippocampal slices obtained from juvenile rats upon induction of long-term plasticity (Bellone and Nicoll, 2007; Matta et al., 2011), suggesting that critical period mechanisms generalize to different brain regions and functional systems. As discussed above, our finding that sim- 
ilar changes occur in the hippocampus of PN17 rats following IA learning led us to suggest the existence of a critical period for hippocampal learning.

Other important mechanisms in the visual system critical period relate to the development of GABAergic inhibitory innervation (Fagiolini and Hensch, 2000; Hensch, 2005). This innervation is crucial for the onset of the visual critical period: decreasing GABAergic function during development blocks the occurrence of the critical period, whereas treatment with $\mathrm{GABA}_{\mathrm{A}}$ receptor agonists restores it (Hensch et al., 1998). The regulation of this inhibition involves parvalbumin-positive $\left(\mathrm{PV}^{+}\right)$neurons, possibly working through the transsynaptic uptake of the transcription factor orthodenticle homeobox 2 (OTX2) (Fagiolini et al., 2004). The regulation of GABAergic inhibition is not selective for the visual cortex critical period, and is also observed in the critical periods for whisker trimming (Jiao et al., 2006) and early hearing (Kotak et al., 2008; Takesian et al., 2010). Thus, although the specific underlying electrophysiological mechanisms remain to be elucidated (Takesian and Hensch, 2013), it has been proposed that a fundamental mechanism underlying critical periods of sensory systems is the shift in excitation/inhibition (E/I) mediated by regulation of GABAergic transmission (Hensch, 2005). Given that several neuropsychiatric disorders, including autism spectrum disorder and schizophrenia, have been linked to an alteration in E/I balance (Rubenstein and Merzenich, 2003; Dani et al., 2005; Chao et al., 2010), dysregulation of critical period mechanisms may contribute to these diseases (LeBlanc and Fagiolini, 2011; Meredith, 2015). Additionally, several known plasticity mechanisms have been identified as key players in modulation of the E/I circuit balance, including calcium/CaMKII, protein kinase A, ERK, TNF $\alpha$, CREB, and microRNA (miR)-132 (Takesian and Hensch, 2013). A master regulator of these plasticity mechanisms is BDNF, which can modulate the opening and closure of the temporal windows of critical periods: transgenic mice that overexpress BDNF have a precocious critical period, possibly due to accelerated maturation of the inhibitory system (Huang et al., 1999), whereas dark rearing downregulates BDNF expression in the visual cortex. It will be interesting to learn whether and how GABAergic inhibition and the $\mathrm{E} / \mathrm{I}$ balance regulate the development of the hippocampal memory system.

The major role of BDNF in controlling the temporal limits of critical periods raises the question of which physical substrates have the ability to close the windows of critical periods. Some of these substrates have been identified and shown to impose physical "brakes" that stabilize the changes shaped by experience. Among these braking mechanisms are the extracellular macromolecular aggregates associated with chondroitin sulfate proteoglycans forming perineuronal nets (PNNs) around neuronal cell bodies and proximal dendrites. Removal of PNNs leads to acceleration of ocular dominance plasticity (Di Cristo et al., 2007). PNN organization is thought to correspond to the ends of critical periods, possibly due to a change in the dynamics of $\mathrm{PV}^{+}$ neurons, and therefore of GABAergic inhibition, as shown to occur in the visual cortex (Sur et al., 1988; Pizzorusso et al., 2002) and barrel cortex (McRae et al., 2007). Interestingly, PNNs also play a role in regulating fear memory plasticity in the amygdala. The abundance of PNNs in the amygdala increases between PN16 and PN23, an interval that corresponds to the establishment of fear memories that are resistant to extinction, and are therefore more persistent (Gogolla et al., 2009). Recent studies reported that PNNs are also present at excitatory synapses of CA2 pyramidal neurons in the adult mouse hippocampus, where they constrain synaptic plasticity. Early-life enrichment increases the abundance of PNNs around these neurons, implying that CA2 and its functions undergo a critical period (Carstens et al., 2016). Some studies link PNN-related regulation of plasticity to OTX2 within PV cells (Beurdeley et al., 2012; Lee et al., 2017). OTX2 is present in $\mathrm{PV}^{+}$cells across multiple brain regions outside of the visual cortex, including prefrontal, auditory, and somatosensory cortices, basolateral amygdala, and hippocampus, suggesting that this factor is a general mechanism involved in $\mathrm{PV}^{+}$cell maturation during critical periods (Spatazza et al., 2013).

Another mechanism that constrains critical periods is myelinrelated neurite outgrowth inhibitor (Nogo) receptor signaling (McGee at al., 2005). Maturation of intracortical myelin and reduction of the myelin-related inhibitors NogoA, myelin-associated glycoprotein, and oligodendrocyte-myelin glycoprotein, all of which bind to the Nogo receptor, accompany the closure of critical periods (Akbik et al., 2012). Notably, restriction of social learning (social isolation) during PN21-PN35, but not during PN35-PN65, alters mPFC oligodendrocyte morphology and myelination, resulting in deficient working memory. This effect persists even after subsequent exposure to social interaction (Makinodan et al., 2012). These data are in agreement with our hypotheses that learning during a critical period is necessary for the development of cognitive abilities and their associated physical changes, including changes in connectivity. Again, it would be interesting to learn how infantile hippocampal learning regulates these myelination mechanisms.

Future studies should attempt to characterize in greater detail the common and differential mechanisms recruited during critical periods of various brain systems and functions. In this regard, it will be important to identify possible common properties among these molecules, and especially to identify approaches that can reopen critical periods, such as targeting of PNNs (Gogolla et al., 2009). This knowledge would expand our understanding of brain development and infantile memories and provide insight into the contribution of developmental dysregulation to disease. It also would facilitate the identification of novel therapeutic tools that may allow for recovery of functional deficits.

\section{Implications of critical periods for developing learning systems and psychopathologies}

Based on the available literature and our recent studies showing that hippocampal learning undergoes a critical period (Travaglia et al., 2016a), we speculate that critical periods in learning do not occur by developmental default but are the results of gradients of experience-induced maturation and are therefore enabled by functional achievement during previous critical periods. We suggest that a series of critical periods are responsible for assembling the functional complexity of the brain, which indeed emerges sequentially over time through experience, building step-by-step on previously established functional competence. We propose that, as with sensory functions, sequences of critical periods for learning and memory also build on each other, following the maturation of sensory system critical periods. Our hypothesis is supported by the observation that complex hippocampal learning takes place only after simple learning has matured. For example, the ability to learn about a single cue or object seems to mature earlier than episodic learning and memory, which require the more complex function of binding together several objects, sequences, and time (wwww learning). Thus, we speculate that different types of hippocampal learning mature sequentially in order of increasing complexity (Fig. 3). An analogous process of sequential maturation has been described in sensory systems, which influence one another during developmental critical peri- 


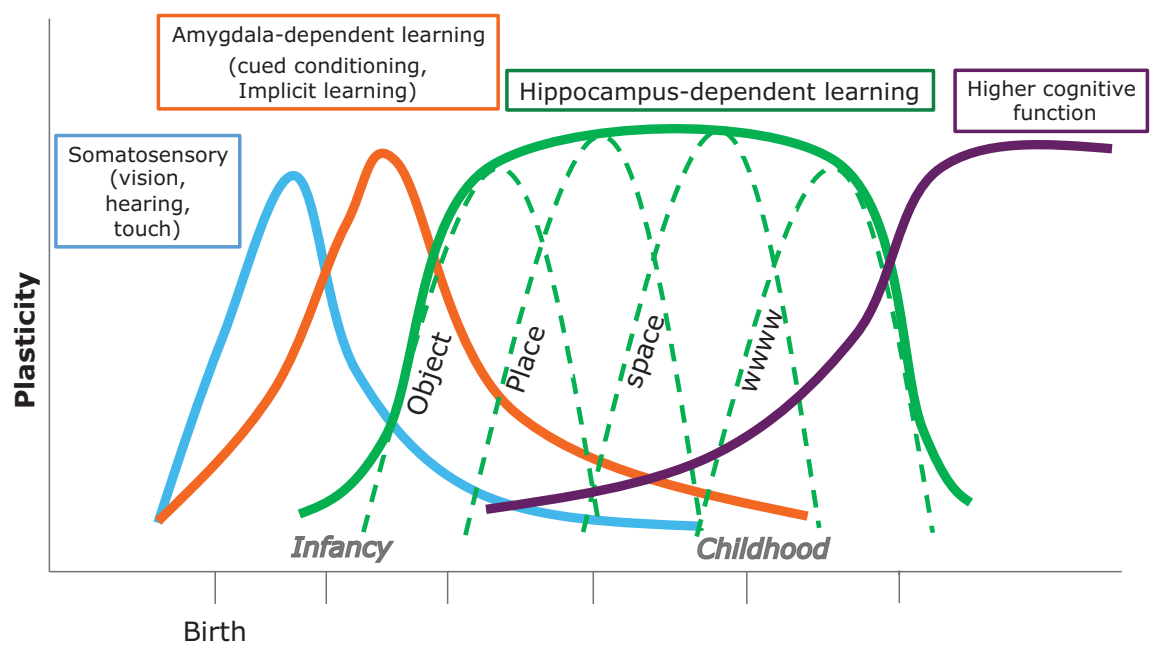

Development

Figure 3. Critical windows of sensitivity for brain functions. Schematic representation of critical periods of brain functions. Solid curve indicates the normal expression of a critical period, with distinct times of onset and closure as well as characteristic duration. Hippocampal-dependent learning includes sequential waves of sensitivity, which enable acquisition of increasingly complex functions.

ods (Hensch, 2005). For example, visual experience influences central auditory development, and atypical onset or delay of visual experience in premature infants can lead to dysfunctions in sensory processing (Mowery et al., 2016).

Our conclusion regarding the existence of critical periods for hippocampal learning provides an explanation for infantile amnesia and resolves several controversies. Furthermore, it has implications for the ontogeny of the hippocampal learning system and its psychopathology.

First, it reconciles some aspects of the disagreement between the developmental and retrieval hypotheses. In agreement with the developmental hypothesis, our model affirms that the hippocampus is indeed immature in infancy. However, we propose that, rather than being "offline," the infantile hippocampus is highly engaged and responsive to experience, a conclusion that is also in agreement with the abundance of associative learning in infants (Mullally and Maguire, 2014). Through these immature but highly active mechanisms, the hippocampus stores latent information that can be retrieved under certain circumstances later in life. These learning-dependent activations contribute to maturation of the hippocampal system as it engages in the process of learning to learn.

On the other hand, in agreement with the retrieval hypothesis, our model indicates that infantile learning leads to (latent) longterm storage. This explains how memory expression can be maintained through frequent recalls, or reinstated by modulation, as shown by the studies cited above that support the retrieval hypothesis. Memory decay may be prevented by frequent reactivation of the memory trace, and internal states such as arousal or modulation may affect memory retrieval or expression of the infantile latent memory trace. We also suggest that, as in the adult brain, where memory reactivation facilitates system consolidation (Inda et al., 2011), reactivation or modulation during early development accelerates the maturation of long-term memory storage.

Second, the existence of hippocampal critical periods explains the differences in learning ability in infants and children versus adults (Spear, 1984; Rovee-Collier and Cuevas, 2009). Our model is in agreement with the fact that infantile and childhood learning is appropriate to the age of the subject because it builds sequen- tially on an ordered gradient of critical periods that lead to the maturation of hippocampus-dependent functions of increasing complexity. This model is also consistent with the differential structural and cellular maturation of distinct circuits in the hippocampus during the early postnatal years of life.

Third, our model of long-lasting memory storage in early life explains the influence of early experiences on lifelong behavior. In addition, it implies that experiences in childhood should be optimally enriched and regulated to promote development of healthy brain and mental functions. Furthermore, it suggests that the types of experience to which an individual is exposed during development shape learning abilities, an important implication that highlights the fundamental roles of developmental environments (including education).

Fourth, our model has intriguing implications for the ontogeny of learning. If maturation occurs through learning and memory reactivation, then the types of experiences and exposures will influence the quality of the hippocampus-dependent functions that develop, and hence the subject's individuality (Greenough et al., 1987). Although the mechanisms underlying rapid forgetting during development remain unknown, we speculate that this phenomenon may be due to differences in plasticity mechanisms in development versus adulthood or the lack of stabilized connectivity in infant brains. One possibility is that the connectivity between the hippocampus and the cortical regions (e.g., mPFC and anterior cingulate cortex, matures as a result of experience). Formation of connectivity, particularly of cortical-cortical connectivity, may explain the establishment of semantic memories.

Finally, several excellent reviews have described the hypothesis that alterations in sensitive and critical periods may contribute significantly to neurodevelopmental disorders (Ben-Ari, 2015; Meredith, 2015); here, we will add our perspective. We suggest that, if one specific critical period is dysregulated, the subsequent chain of critical periods is likely to be altered, leading to developmental disruption or delay of multiple functions. This hypothesis explains why neuropsychiatric developmental disorders encompass many domains and functions, as well as why disparate developmental disorders exhibit common cellular/molecular alterations, such as impaired synapse maturation and excitation/ inhibition imbalance. Neuropsychiatric developmental disorders could be due to dysregulation of mechanisms of developmental critical periods, which would disrupt or delay synapse and circuitry development. Consistent with this idea, mutations in a single gene that is essential for some function during a critical period could lead to several subsequent cellular defects and manifest as multiple phenotypes. This model would also explain why timing is critically important for interventions that rescue developmental dysfunctions (Gatto and Broadie, 2009; Manent et al., 2009). In sum, a great wealth of knowledge about learning and memory during development in both normal and abnormal conditions, in animal models as well as in human studies, is consistent with our suggestion of the existence of critical period(s) for hippocampal learning. 


\section{Conclusions and future directions}

Based on our recent studies, we propose that the hippocampus undergoes a developmental critical period similar to those implicated in development of vision, hearing, language learning, song learning in birds, and familial imprinting. This new view of experience-dependent functional maturation of the hippocampal system resolves the paradoxical observation that early experiences that are forgotten very rapidly can have long-lasting influences on adult behavior, as well as predispose individuals to disorders or psychopathologies. In contrast to previous hypotheses suggesting that the hippocampus is deficient in early development, and hence not functionally competent, our new model of infantile learning proposes that the hippocampus and hippocampal learning system are highly engaged in processing of early experiences and storing infantile memories. Accordingly, early learning during infancy is itself critical for shaping learning, memory, and cognitive functions of adult brains. This view of the ontogeny of the hippocampus-dependent learning system has important implications for the developmental environment (e.g., family, education), as well as possible interventions aimed at preventing psychopathologies. Future studies should continue to identify the mechanisms underlying hippocampal critical periods, as well as their temporal regulation; determine their interaction with other brain areas; and compile information about individual learning. Cooperative studies in humans and nonhuman animals may help to define the best strategies for capitalizing on the understanding of mechanisms and temporal windows of critical periods in learning.

\section{References}

Aamodt SM, Nordeen EJ, Nordeen KW (1996) Blockade of NMDA receptors during song model exposure impairs song development in juvenile zebra finches. Neurobiol Learn Mem 65:91-98. CrossRef Medline

Ainge JA, Langston RF (2012) Ontogeny of neural circuits underlying spatial memory in the rat. Front Neural Circuits 6:8. CrossRef Medline

Akbik F, Cafferty WB, Strittmatter SM (2012) Myelin associated inhibitors: a link between injury-induced and experience-dependent plasticity. Exp Neurol 235:43-52. CrossRef Medline

Akers KG, Hamilton DA (2007) Comparison of developmental trajectories for place and cued navigation in the Morris water task. Dev Psychobiol 49:553-564. CrossRef Medline

Akers KG, Candelaria-Cook FT, Rice JP, Johnson TE, Hamilton DA (2009) Delayed development of place navigation compared to directional responding in young rats. Behav Neurosci 123:267-275. CrossRef Medline

Akers KG, Martinez-Canabal A, Restivo L, Yiu AP, De Cristofaro A, Hsiang HL, Wheeler AL, Guskjolen A, Niibori Y, Shoji H, Ohira K, Richards BA, Miyakawa T, Josselyn SA, Frankland PW (2014) Hippocampal neurogenesis regulates forgetting during adulthood and infancy. Science 344: 598-602. CrossRef Medline

Albani SH, McHail DG, Dumas TC (2014) Developmental studies of the hippocampus and hippocampal-dependent behaviors: insights from interdisciplinary studies and tips for new investigators. Neurosci Biobehav Rev 43:183-190. CrossRef Medline

Alberts JR (1984) Sensory-perceptual development in the Norway rat: a view toward comparative studies. In: Comparative perspectives on memory development. (Kail R, Spear NS, eds), pp 65-101. Hillsdale, NJ: Erlbaum.

Anderson MJ, Barnes GW, Briggs JF, Ashton KM, Moody EW, Joynes RL, Riccio DC (2004) Effects of ontogeny on performance of rats in a novel object-recognition task. Psychol Rep 94:437-443. CrossRef Medline

Bale TL, Baram TZ, Brown AS, Goldstein JM, Insel TR, McCarthy MM, Nemeroff CB, Reyes TM, Simerly RB, Susser ES, Nestler EJ (2010) Early life programming and neurodevelopmental disorders Biol Psychiatry 68: 314-319. CrossRef Medline

Bambah-Mukku D, Travaglia A, Chen DY, Pollonini G, Alberini CM (2014) A positive autoregulatory BDNF feedback loop via C/EBP $\beta$ mediates hippocampal memory consolidation. J Neurosci 34:12547-12559. CrossRef Medline
Bath KG, Manzano-Nieves G, Goodwill H (2016) Early life stress accelerates behavioral and neural maturation of the hippocampus in male mice. Horm Behav 82:64-71. CrossRef Medline

Bauer PJ (2006) Constructing a past in infancy: a neuro-developmental account. Trends Cogn Sci 10:175-181. CrossRef Medline

Bauer PJ, Larkina M, Doydum AO (2012) Explaining variance in long-term recall in 3- and 4-year-old children: the importance of post-encoding processes. J Exp Child Psychol 113:195-210. CrossRef Medline

Bellone C, Nicoll RA (2007) Rapid bidirectional switching of synaptic NMDA receptors. Neuron 55:779-785. CrossRef Medline

Ben-Ari Y (2015) Is birth a critical period in the pathogenesis of autism spectrum disorders? Nat Rev Neurosci 16:498-505. CrossRef Medline

Beurdeley M, Spatazza J, Lee HH, Sugiyama S, Bernard C, Di Nardo AA, Hensch TK, Prochiantz A (2012) Otx2 binding to perineuronal nets persistently regulates plasticity in the mature visual cortex. J Neurosci 32:9429-9437. CrossRef Medline

Blair C, Raver CC (2016) Poverty, stress, and brain development: new directions for prevention and intervention. Acad Pediatr 16:S30-S36. CrossRef Medline

Blair MG, Nguyen NN, Albani SH, L'Etoile MM, Andrawis MM, Owen LM, Oliveira RF, Johnson MW, Purvis DL, Sanders EM, Stoneham ET, Xu H, Dumas TC (2013) Developmental changes in structural and functional properties of hippocampal AMPARs parallels the emergence of deliberative spatial navigation in juvenile rats. J Neurosci 33:12218-12228. CrossRef Medline

Bos KJ, Zeanah CH Jr, Smyke AT, Fox NA, Nelson CA 3rd (2010) Stereotypies in children with a history of early institutional care. Arch Pediatr Adolesc Med 164:406-411. CrossRef Medline

Bouwmeester H, Wolterink G, van Ree JM (2002) Neonatal development of projections from the basolateral amygdala to prefrontal, striatal, and thalamic structures in the rat. J Comp Neurol 442:239-249. CrossRef Medline

Bruer JT (2008) Critical periods in second language learning: distinguishing phenomena from explanation. In: Brain, behavior and learning in language and reading disorders (Mody M, Silliman E, eds), pp 72-96. New York: Guilford.

Brunson KL, Kramár E, Lin B, Chen Y, Colgin LL, Yanagihara TK, Lynch G, Baram TZ (2005) Mechanisms of late-onset cognitive decline after early-life stress. J Neurosci 25:9328-9338. CrossRef Medline

Callaghan BL, Richardson R (2012) The effect of adverse rearing environments on persistent memories in young rats: removing the brakes on infant fear memories. Transl Psychiatry 2:e138. CrossRef Medline

Callaghan BL, Li S, Richardson R (2014) The elusive engram: what can infantile amnesia tell us about memory? Trends Neurosci 37:47-53. CrossRef Medline

Campbell BA, Campbell EH (1962) Retention and extinction of learned fear in infant and adult rats. J Comp Physiol Psychol 55:1-8. CrossRef Medline

Campbell BA, Jaynes J (1966) Reinstatement. Psychol Rev 73:478-480. CrossRef Medline

Campbell BA, Spear NE (1972) Ontogeny of memory. Psychol Rev 79:215236. CrossRef Medline

Carmignoto G, Vicini S (1992) Activity-dependent decrease in NMDA receptor responses during development of the visual cortex. Science 258: 1007-1011. CrossRef Medline

Carstens KE, Phillips ML, Pozzo-Miller L, Weinberg RJ, Dudek SM (2016) Perineuronal nets suppress plasticity of excitatory synapses on CA2 pyramidal neurons. J Neurosci 36:6312-6320. CrossRef Medline

Carver LJ, Bauer PJ (2001) The dawning of a past: the emergence of longterm explicit memory in infancy. J Exp Psychol Gen 130:726-745. CrossRef Medline

Chan D, Baker KD, Richardson R (2015) Relearning a context-shock association after forgetting is an NMDAr-independent process. Physiol Behav 1:29-35. CrossRef Medline

Chao HT, Chen H, Samaco RC, Xue M, Chahrour M, Yoo J, Neul JL, Gong S, Lu HC, Heintz N, Ekker M, Rubenstein JL, Noebels JL, Rosenmund C, Zoghbi HY (2010) Dysfunction in GABA signalling mediates autismlike stereotypies and Rett syndrome phenotypes. Nature 468:263-269. CrossRef Medline

Chareyron LJ, Lavenex PB, Lavenex P (2012) Postnatal development of the amygdala: a stereological study in rats. J Comp Neurol 520:3745-3763. CrossRef Medline 
Chocyk A, Chen H, Samaco RC, Xue M, Chahrour M, Yoo J, Neul JL, Gong S, Lu HC, Heintz N, Ekker M, Rubenstein JL, Noebels JL, Rosenmund C, Zoghbi HY (2013) Early-life stress affects the structural and functional plasticity of the medial prefrontal cortex in adolescent rats. Eur J Neurosci 38:2089-2107. CrossRef Medline

Cooke SF, Bear MF (2014) How the mechanisms of long-term synaptic potentiation and depression serve experience-dependent plasticity in primary visual cortex. Philos Trans R Soc Lond B Biol Sci 369:20130284. CrossRef Medline

Dani VS, Chang Q, Maffei A, Turrigiano GG, Jaenisch R, Nelson SB (2005) Reduced cortical activity due to a shift in the balance between excitation and inhibition in a mouse model of Rett syndrome. Proc Natl Acad Sci U S A 102:12560-12565. CrossRef Medline

Davis JM, Rovee-Collier CK (1983) Alleviated forgetting of a learned contingency in 8-week-old infants. Dev Psychol 19:353-365. CrossRef

de Villers-Sidani E, Chang EF, Bao S, Merzenich MM (2007) Critical period window for spectral tuning defined in the primary auditory cortex (A1) in the rat. J Neurosci 27:180-189. CrossRef Medline

Di Cristo G, Chattopadhyaya B, Kuhlman SJ, Fu Y, Bélanger MC, Wu CZ, Rutishauser U, Maffei L, Huang ZJ (2007) Activity-dependent PSA expression regulates inhibitory maturation and onset of critical period plasticity. Nat Neurosci 10:1569-1577. CrossRef Medline

Dudai Y (2012) The restless engram: consolidations never end. Annu Rev Neurosci 35:227-247. CrossRef Medline

Eales LA (1985) Song learning in zebra finches: some effects of song model availability on what is learnt and when. Anim Behav 33:1293-1300. CrossRef

Eichenbaum H (2006) Remembering: functional organization of the declarative memory system. Curr Biol 16:R643-R645. CrossRef Medline

Ergorul C, Eichenbaum H (2004) The hippocampus and memory for "what," "where," and "when." Learn Mem 11:397-405.

Ewald RC, Cline HT (2009) NMDA receptors and brain development. In: Biology of the NMDA receptor (Van Dongen AM, ed). Boca Raton, FL: CRC/Taylor and Francis.

Fagiolini M, Hensch TK (2000) Inhibitory threshold for critical-period activation in primary visual cortex. Nature 404:183-186. CrossRef Medline

Fagiolini M, Fritschy JM, Löw K, Möhler H, Rudolph U, Hensch TK (2004) Specific GABAA circuits for visual cortical plasticity. Science 303:16811683. CrossRef Medline

Feigley DA, Spear NE (1970) Effect of age and punishment condition on long-term retention by the rat of active- and passive-avoidance learning. J Comp Physiol Psychol 73:515-526. CrossRef Medline

Feldman DE, Knudsen EI (1997) An anatomical basis for visual calibration of the auditory space map in the barn owl's midbrain. J Neurosci 17: 6820-6837. Medline

Fisher PA (2016) Translational neuroscience as a tool for intervention development in the context of high-adversity families. New Dir Child Adolesc Dev 153:111-125. CrossRef Medline

Freeman S, Geal-Dor M, Sohmer H (1999) Development of inner ear (cochlear and vestibular) function in the fetus-neonate. J Basic Clin Physiol Pharmacol 10:173-189. Medline

Freud S (1953) Three essays on the theory of sexuality. In: The standard edition of the complete psychological works of Sigmund Freud (Strachey J, ed, translator), pp 125-245. London: Hogarth.

Ganella DE, Allen NB, Simmons JG, Schwartz O, Kim JH, Sheeber L, Whittle S (2015) Early life stress alters pituitary growth during adolescence, a longitudinal study. Psychoneuroendocrinology 53:185-194. CrossRef Medline

Gatto CL, Broadie K (2009) Temporal requirements of the fragile X mental retardation protein in modulating circadian clock circuit synaptic architecture. Front Neural Circuits 20:3-8. CrossRef Medline

Gee DG, Gabard-Durnam LJ, Flannery J, Goff B, Humphreys KL, Telzer EH, Hare TA, Bookheimer SY, Tottenham N (2013) Early developmental emergence of human amygdala-prefrontal connectivity after maternal deprivation. Proc Natl Acad Sci U S A 110:15638-15643. CrossRef Medline

Gogolla N, Caroni P, Lüthi A, Herry C (2009) Perineuronal nets protect fear memories from erasure. Science 325:1258-1261. CrossRef Medline

Gold PE, Murphy JM, Cooley S (1982) Neuroendocrine modulation of memory during development Behav Neural Biol 35:277-293. Medline

Goldman-Rakic PS (1987) Development of cortical circuitry and cognitive function. Child Dev 58:601-622. CrossRef Medline
Graf P, Schacter DL (1985) Implicit and explicit memory for new associations in normal and amnesic subjects. J Exp Psychol Learn Mem Cogn 11:501-518. CrossRef Medline

Greco C, Rovee-Collier C, Hayne H, Griesler P, Earley L (1986) Ontogeny of early event memory: I. Forgetting and retrieval by 2 - and 3-month-olds. Infant Behav Dev 9:441-460. CrossRef

Greenough WT, Black JE, Wallace CS (1987) Experience and brain development. Child Dev 58:539-559. CrossRef Medline

Hair NL, Hanson JL, Wolfe BL, Pollak SD (2015) Association of child poverty, brain development, and academic achievement. JAMA Pediatr 169: 822-829. CrossRef Medline

Harley K, Reese E (1999) Origins of autobiographical memory. Dev Psychol 35:1338-1348. CrossRef Medline

Haroutunian V, Riccio DC (1977) Effect of arousal conditions during reinstatement treatment upon learned fear in young rats. Dev Psychobiol 10:25-32. CrossRef Medline

Hayne H (2004) Infant memory development: implications for childhood amnesia. Dev Rev 24:33-73. CrossRef

Hayne H, Imuta K (2011) Episodic memory in 3- and 4-year-old children. Dev Psychobiol 53:317-322. CrossRef Medline

Heim C, Nemeroff CB (2001) The role of childhood trauma in the neurobiology of mood and anxiety disorders: preclinical and clinical studies. Biol Psychiatry 49:1023-1039. CrossRef Medline

Henri V, Henri C (1895) On our earliest recollections of childhood. Psychol Rev 2:215-216.

Hensch TK (2005) Critical period plasticity in local cortical circuits. Nat Rev Neurosci 6:877-888. CrossRef Medline

Hensch TK, Fagiolini M, Mataga N, Stryker MP, Baekkeskov S, Kash SF (1998) Local GABA circuit control of experience-dependent plasticity in developing visual cortex. Science 282:1504-1508. CrossRef Medline

Huang ZJ, Kirkwood A, Pizzorusso T, Porciatti V, Morales B, Bear MF, Maffei L, Tonegawa S (1999) BDNF regulates the maturation of inhibition and the critical period of plasticity in mouse visual cortex. Cell 98:739-755. CrossRef Medline

Huttenlocher PR (1979) Synaptic density in human frontal cortex, developmental changes and effects of aging. Brain Res 163:195-205. CrossRef Medline

Huttenlocher PR, Dabholkar AS (1997) Regional differences in synaptogenesis in human cerebral cortex. J Comp Neurol 387:167-178. CrossRef Medline

Immelmann K (1969) Song development in the zebra finch and other estrildid finches. In: Bird vocalizations (Hinde RA, ed), pp 61-77. Cambridge: Cambridge UP.

Inda MC, Muravieva EV, Alberini CM (2011) Memory retrieval and the passage of time: from reconsolidation and strengthening to extinction. J Neurosci 31:1635-1643. CrossRef Medline

Ivkovich D, Paczkowski CM, Stanton ME (2000) Ontogeny of delay versus trace eyeblink conditioning in the rat. Dev Psychobiol 36:148-160. CrossRef Medline

Jablonski SA, Schiffino FL, Stanton ME (2012) Role of age, post-training consolidation, and conjunctive associations in the ontogeny of the context preexposure facilitation effect. Dev Psychobiol 54:714-722. CrossRef Medline

Jiao Y, Zhang C, Yanagawa Y, Sun QQ (2006) Major effects of sensory experiences on the neocortical inhibitory circuits. J Neurosci 26:8691-8701. CrossRef Medline

Khibnik LA, Cho KK, Bear MF (2010) Relative contribution of feedforward excitatory connections to expression of ocular dominance plasticity in layer 4 of visual cortex. Neuron 66:493-500. CrossRef Medline

Kihlstrom JF, Harackiewicz JM (1982) The earliest recollection: a new survey. J Pers 50:134-148. CrossRef

Kim JH, Richardson R (2007) Immediate post-reminder injection of gamma-amino butyric acid (GABA) agonist midazolam attenuates reactivation of forgotten fear in the infant rat. Behav Neurosci 121:13281332. CrossRef Medline

Kim JH, McNally GP, Richardson R (2006) Recovery of fear memories in rats: role of gamma-amino butyric acid (GABA) in infantile amnesia. Behav Neurosci 120:40-48. CrossRef Medline

Kim JH, Li S, Hamlin AS, McNally GP, Richardson R (2012) Phosphorylation of mitogen-activated protein kinase in the medial prefrontal cortex and the amygdala following memory retrieval or forgetting in developing rats. Neurobiol Learn Mem 97:59-68. CrossRef Medline 
Kim JJ, Fanselow MS (1992) Modality-specific retrograde amnesia of fear. Science 256:675-677. CrossRef Medline

Kirby RH (1963) Acquisition extinction, and retention of an avoidance response in rats as a function of age. J Comp Physiol Psychol 56:158-162. CrossRef

Klein SB, Spear NE (1969) Influence of age on short-term retention of active-avoidance learning in rats. J Comp Physiol Psychol 69:583-589. CrossRef Medline

Knudsen EI (2004) Sensitive periods in the development of the brain and behavior. J Cogn Neurosci 16:1412-1425. CrossRef Medline

Kotak VC, Takesian AE, Sanes DH (2008) Hearing loss prevents the maturation of GABAergic transmission in the auditory cortex. Cereb Cortex 18:2098-2108. CrossRef Medline

Kraemer PJ, Randall CK (1995) Spatial-learning in preweanling rats trained in a Morris water maze. Psychobiology 23:144-152.

Kuhl PK (2004) Early language acquisition: cracking the speech code. Nat Rev Neurosci 5:831-843. CrossRef Medline

Landers MS, Sullivan RM (1999) Vibrissae evoked behavior and conditioning before functional ontogeny of somatosensory vibrissae cortex. J Neurosci 19:5131-5137. Medline

Lavenex P, Banta Lavenex P (2013) Building hippocampal circuits to learn and remember: insights into the development of human memory. Behav Brain Res 254:8-21. CrossRef Medline

LeBlanc JJ, Fagiolini M (2011) Autism: a "critical period" disorder? Neural Plast 2011:921680. CrossRef Medline

Lee HH, Bernard C, Ye Z, Acampora D, Simeone A, Prochiantz A, Di Nardo AA, Hensch TK (2017) Genetic Otx2 mis-localization delays critical period plasticity across brain regions. Mol Psychiatry 22:680-688. CrossRef Medline

Lehmann J, Feldon J (2000) Long-term biobehavioral effects of maternal separation in the rat: consistent or confusing? Rev Neurosci 11:383-408. Medline

Li S, Richardson R (2013) Traces of memory: reacquisition of fear following forgetting is NMDAr-independent. Learn Mem 20:174-182. CrossRef Medline

Li S, Callaghan BL, Richardson R (2014) Infantile amnesia: forgotten but not gone. Learn Mem 21:135-139. CrossRef Medline

Lorenz K (1935) Der Kumpan in der Umwelt des Vogels. Der Artgenosse als auslösendes Moment sozialer Verhaltensweisen. J Ornithologie 83:137215. CrossRef

Luria AR (1968) The mind of a mnemonist. In: A little book about a vast memory (Solataroff L, translator). New York: Basic.

Lyons-Ruth K, Dutra L, Schuder MR, Bianchi I (2006) From infant attachment disorganization to adult dissociation: relational adaptations or traumatic experiences? Psychiatr Clin North Am 29:63-86. CrossRef Medline

Madsen HB, Kim JH (2016) Ontogeny of memory: an update on 40 years of work on infantile amnesia. Behav Brain Res 298:4-14. CrossRef Medline

Makinodan M, Rosen KM, Ito S, Corfas G (2012) A critical period for social experience-dependent oligodendrocyte maturation and myelination. Science 337:1357-1360. CrossRef Medline

Manent JB, Wang Y, Chang Y, Paramasivam M, LoTurco JJ (2009) Dcx reexpression reduces subcortical band heterotopia and seizure threshold in an animal model of neuronal migration disorder. Nat Med 15:84-90. CrossRef Medline

Matta JA, Ashby MC, Sanz-Clemente A, Roche KW, Isaac JT (2011) mGluR5 and NMDA receptors drive the experience- and activity-dependent NMDA receptor NR2B to NR2A subunit switch. Neuron 70:339-351. CrossRef Medline

McGee AW, Yang Y, Fischer QS, Daw NW, Strittmatter SM (2005) Experience-driven plasticity of visual cortex limited by myelin and Nogo receptor. Science 309:2222-2226. CrossRef Medline

McRae PA, Rocco MM, Kelly G, Brumberg JC, Matthews RT (2007) Sensory deprivation alters aggrecan and perineuronal net expression in the mouse barrel cortex. J Neurosci 27:5405-5413. CrossRef Medline

Meaney MJ, Szyf M (2005) Environmental programming of stress responses through DNA methylation: life at the interface between a dynamic environment and a fixed genome. Dialogues Clin Neurosci 7:103-123. Medline

Meaney MJ, Aitken DH, van Berkel C, Bhatnagar S, Sapolsky RM (1988) Effect of neonatal handling on age-related impairments associated with the hippocampus. Science 239:766-768. CrossRef Medline

Medini P (2011) Layer- and cell type-specific subthreshold and suprath- reshold effects of long-term monocular deprivation in rat visual cortex. J Neurosci 31:17134-17148. CrossRef Medline

Meltzoff AN (1988) Imitation of televised models by infants. Child Dev 59:1221-1229. CrossRef Medline

Meredith RM (2015) Sensitive and critical periods during neurotypical and aberrant neurodevelopment: a framework for neurodevelopmental disorders. Neurosci Biobehav Rev 50:180-188. CrossRef Medline

Moriceau S, Sullivan RM (2006) Maternal presence serves as a switch between learning fear and attraction in infancy. Nat Neurosci 9:1004-1006. CrossRef Medline

Moriceau S, Wilson DA, Levine S, Sullivan RM (2006) Dual circuitry for odor-shock conditioning during infancy: corticosterone switches between fear and attraction via amygdala. J Neurosci 26:6737-6748. CrossRef Medline

Moscovitch M, Cabeza R, Winocur G, Nadel L (2016) Episodic memory and beyond: the hippocampus and neocortex in transformation. Annu Rev Psychol 67:105-134. CrossRef Medline

Mowery TM, Kotak VC, Sanes DH (2016) The onset of visual experience gates auditory cortex critical periods. Nat Commun 7:10416. CrossRef Medline

Moye TB, Rudy JW (1987) Ontogenesis of trace conditioning in young rats: dissociation of associative and memory processes. Dev Psychobiol 20: 405-414. CrossRef Medline

Mullally SL, Maguire EA (2014) Learning to remember: the early ontogeny of episodic memory. Dev Cogn Neurosci 9:12-29. CrossRef Medline

Nelson CA 3rd, Zeanah CH, Fox NA, Marshall PJ, Smyke AT, Guthrie D (2007) Cognitive recovery in socially deprived young children: the Bucharest Early Intervention Project. Science 318:1937-1940. CrossRef Medline

Newcombe NS, Lloyd ME, Ratliff KR (2007) Development of episodic and autobiographical memory: a cognitive neuroscience perspective. Adv Child Dev Behav 35:37-85. CrossRef Medline

Newport EL, Bavelier D, Neville HJ (2001) Critical thinking about critical periods: perspectives on a critical period for language acquisition. In: Language, brain, and cognitive development: essays in honor of Jacques Mehlter (Dupoux E, ed), pp 481-502). Cambridge, MA: Massachusetts Institute of Technology.

Perner J, Ruffman T (1995) Episodic memory and autonoetic consciousness: developmental evidence and a theory of childhood amnesia. J Exp Child Psychol 59:516-548. CrossRef Medline

Perry R, Sullivan RM (2014) Neurobiology of attachment to an abusive caregiver: short-term benefits and long-term costs. Dev Psychobiol 56: 1626-1634. CrossRef Medline

Pizzorusso T, Medini P, Berardi N, Chierzi S, Fawcett JW, Maffei L (2002) Reactivation of ocular dominance plasticity in the adult visual cortex. Science 298:1248-1251. CrossRef Medline

Pollak SD (2015) Multilevel developmental approaches to understanding the effects of child maltreatment: recent advances and future challenges. Dev Psychopathol 27:1387-1397. CrossRef Medline

Poulos AM, Reger M, Mehta N, Zhuravka I, Sterlace SS, Gannam C, Hovda DA, Giza CC, Fanselow MS (2014) Amnesia for early life stress does not preclude the adult development of posttraumatic stress disorder symptoms in rats. Biol Psychiatry 76:306-314. CrossRef Medline

Preston AR, Eichenbaum H (2013) Interplay of hippocampus and prefrontal cortex in memory. Curr Biol 23:R764-R773. CrossRef Medline

Pryce CR, Rüedi-Bettschen D, Dettling AC, Weston A, Russig H, Ferger B, Feldon J (2005) Long-term effects of early-life environment manipulations in rodents and primates: potential animal models in depression research. Neurosci Biobehav Rev 29:649-674. CrossRef Medline

Pugh CR, Rudy JW (1996) A developmental analysis of contextual fear conditioning. Dev Psychobiol 29:87-100. CrossRef Medline

Quinlan EM, Philpot BD, Huganir RL, Bear MF (1999) Rapid, experiencedependent expression of synaptic NMDA receptors in visual cortex in vivo. Nat Neurosci 2:352-357. CrossRef Medline

Reincke SA, Hanganu-Opatz IL (2017) Early-life stress impairs recognition memory and perturbs the functional maturation of prefrontal-hippocampalperirhinal networks. Sci Rep 7:42042. CrossRef Medline

Richardson R, Riccio DC, Axiotis R (1986) Alleviation of infantile amnesia in rats by internal and external contextual cues. Dev Psychobiol 19:453462. CrossRef Medline

Roberts TF, Tschida KA, Klein ME, Mooney R (2010) Rapid spine stabiliza- 
tion and synaptic enhancement at the onset of behavioural learning. Nature 463:948-952. CrossRef Medline

Rovee-Collier C, Cuevas K (2009) The development of infant memory. In: The development of memory in infancy and childhood (Courage ML, Cowan N, eds). New York: Psychology.

Rovee-Collier CK, Sullivan MW, Enright M, Lucas D, Fagen JW (1980) Reactivation of infant memory. Science 208:1159-1161. CrossRef Medline

Rubenstein JL, Merzenich MM (2003) Model of autism: increased ratio of excitation/inhibition in key neural systems. Genes Brain Behav 2:255267. CrossRef Medline

Rubin DC (2000) The distribution of early childhood memories. Memory 8:265-269. CrossRef Medline

Rudy JW, Stadler-Morris S, Albert P (1987) Ontogeny of spatial navigation behaviors in the rat, dissociation of proximal- and distal-cue-based behaviors. Behav Neurosci 101:62-73. CrossRef Medline

Rutter M (1998) Developmental catch-up, and deficit, following adoption after severe global early privation. J Child Psychol Psychiatry 39:465-476. CrossRef Medline

Scarf D, Gross J, Colombo M, Hayne H (2013) To have and to hold: episodic memory in 3- and 4-year-old children. Dev Psychobiol 55:125-132. CrossRef Medline

Schacter DL, Moscovitch M (1984) Infants, amnesics, and dissociable memory systems. In: Infant memory (Moscovitch M, ed), pp 173-216. New York: Plenum.

Schulenburg CJ, Riccio DC, Stikes ER (1971) Acquisition and retention of a passive-avoidance response as a function of age in rats. J Comp Physiol Psychol 74:75-83. CrossRef Medline

Schweitzer L, Green L (1982) Acquisition and extended retention of a conditioned taste aversion in preweanling rats. J Comp Physiol Psychol 96: 791-806. CrossRef Medline

Scoville WB, Milner B (1957) Loss of recent memory after bilateral hippocampal lesions. J Neurol Neurosurg Psychiatry 20:11-21. CrossRef Medline

Shionoya K, Moriceau S, Lunday L, Miner C, Roth TL, Sullivan RM (2006) Development switch in neural circuitry underlying odor-malaise learning. Learn Mem 13:801-808. CrossRef Medline

Sidorov MS, Kaplan ES, Osterweil EK, Lindemann L, Bear MF (2015) Metabotropic glutamate receptor signaling is required for NMDA receptor-dependent ocular dominance plasticity and LTD in visual cortex. Proc Natl Acad Sci U S A 112:12852-12857. CrossRef Medline

Spatazza J, Di Lullo E, Joliot A, Dupont E, Moya KL, Prochiantz A (2013) Homeoprotein signaling in development, health, and disease: a shaking of dogmas offers challenges and promises from bench to bed. Pharmacol Rev 65:90-104. CrossRef Medline

Spear NE (1984) The future study of learning and memory from a psychobiological perspective. In: Perspectives in psychological experimentation (Sarris V, Parducci A, eds), pp 87-103. Hillsdale, NJ: Erlbaum.

Spear NE, Parsons PJ (1976) Analysis of a reactivation treatment: ontoge- netic determinants of alleviated forgetting. In: Processes in animal memory (Medin DL, et al., eds), pp 136-165. Hillsdale, NJ: Erlbaum.

Spratt EG, Friedenberg SL, Swenson CC, Larosa A, De Bellis MD, Macias MM, Summer AP, Hulsey TC, Runyan DK, Brady KT (2012) The effects of early neglect on cognitive, language, and behavioral functioning in childhood. Psychology (Irvine) 3:175-182. CrossRef Medline

Squire LR, Wixted JT (2011) The cognitive neuroscience of human memory since H.M. Annu Rev Neurosci 34:259-288. CrossRef Medline

Squire LR, Genzel L, Wixted JT, Morris RG (2015) Memory consolidation. Cold Spring Harb Perspect Biol 7:a021766. CrossRef Medline

Stanton ME (2000) Multiple memory systems, development and conditioning. Behav Brain Res 110:25-37. CrossRef Medline

Steinert PA, Infurna RN, Spear NE (1980) Long-term retention of a conditioned taste aversion in preweanling and adult rats. Anim Learn Behav 8:375-381. CrossRef

Sullivan RM, Hofer MA, Brake SC (1986) Olfactory-guided orientation in neonatal rats is enhanced by a conditioned change in behavioral state. Dev Psychobiol 19:615-623. CrossRef Medline

Sur M, Garraghty PE, Roe AW (1988) Experimentally induced visual projections into auditory thalamus and cortex. Science 242:1437-1441. CrossRef Medline

Takesian AE, Hensch TK (2013) Balancing plasticity/stability across brain development. Prog Brain Res 207:3-34. CrossRef Medline

Takesian AE, Kotak VC, Sanes DH (2010) Presynaptic GABA(B) receptors regulate experience-dependent development of inhibitory short-term plasticity. J Neurosci 30:2716-2727. CrossRef Medline

Teicher MH, Samson JA (2016) Annual research review: enduring neurobiological effects of childhood abuse and neglect. J Child Psychol Psychiatry 57:241-266. CrossRef Medline

Travaglia A, Bisaz R, Sweet ES, Blitzer RD, Alberini CM (2016a) Infantile amnesia reflects a developmental critical period for hippocampal learning. Nat Neurosci 19:1225-1233. CrossRef Medline

Travaglia A, Bisaz R, Cruz E, Alberini CM (2016b) Developmental changes in plasticity, synaptic, glia and connectivity protein levels in rat dorsal hippocampus. Neurobiol Learn Mem 135:125-138. CrossRef Medline

Tulving E (2005) Episodic memory and autonoesis: uniquely human? In: The missing link in cognition (Terrace HS, Metcalfe J, eds), pp 4-56. New York: Oxford UP.

Van Eden CG, Uylings HB (1985) Cytoarchitectonic development of the prefrontal cortex in the rat. J Comp Neurol 241:253-267. CrossRef Medline

Wiesel TN, Hubel DH (1963) Single-cell responses in striate cortex of kittens deprived of vision in one eye. J Neurophysiol 26:1003-1017. Medline

Zeanah CH, Egger HL, Smyke AT, Nelson CA, Fox NA, Marshall PJ, Guthrie D (2009) Institutional rearing and psychiatric disorders in Romanian preschool children. Am J Psychiatry 166:777-785. CrossRef Medline

Zhang ZW (2004) Maturation of layer V pyramidal neurons in the rat prefrontal cortex: intrinsic properties and synaptic function. J Neurophysiol 91:1171-1182. CrossRef Medline 